\title{
How to measure SCRES? - the perspective of flexibility and redundancy in relationships with suppliers
}

\author{
Grażyna Wieteska \\ University of Łódź
}

\section{Introduction}

In recent years, the concept of risk management and the concept of business continuity management have developed into a broad approach, which is supply chain resilience (SCRES). Interest in this subject began when the Christopher and Peck published an article presenting considerations on the need to reduce supply chain vulnerabilities' ${ }^{1}$ The authors understood resilience as 'the ability of a system to return to its original state or move to a new, more desirable state after being disturbed', a definition which refers mainly to a situation when a disruption has already happened. Over the years, the SCRES concept has developed from covering not only the stage of response, but also the issue of proactive and concurrent strategies $^{2}$, and it is now generally claimed that flexibility and redundancy practices play a key role in building supply chain resilience 3 . This is why these two elements we chosen as the subject of the following considerations.

$1 \quad$ M. Christopher, H. Peck, Building the resilient supply chain, "The International Journal of Logistics Management" 2004, vol. 15, no. 2, pp. 1-14.

2 B.R. Tukamuhabwa et al., Supply chain resilience: definition, review and theoretical foundations for further study, "International Journal of Production Research" 2015, vol. 53, no. 18, pp. 5592-5623; A. Ali, A. Mahfouz, A. Arisha, Analysing supply chain resilience: integrating the constructs in a concept mapping framework via a systematic literature review, "Supply Chain Management: An International Journal" 2017, vol. 22, no. 1, pp. 16-39.

3 C.R. Pereira, M. Christopher, A. Lago Da Silva, Achieving supply chain resilience: the role of procurement, "Supply Chain Management: An International Journal" 2014, vol. 19, no. 5/6, pp. 626-642; N.O. Hohenstein et al., Research on the phenomenon of supply chain resilience: 
SCRES is based on a wide definition of the supply chain, which is known as the network of organizations and interconnected value adding processes ${ }^{4}$. While previous publications focused primarily on the general resilience aspect in the entire supply chain, the basis for the considerations below is the assumption that building resilience in the supply chain should be tailored to individual processes in the network. Namely, risk mitigation and business continuity, which are practices specific to a given area of the supply chain. For example, having alternative suppliers of components will be connected to purchasing5.

According to the well-known supply chain management models (e.g. SCOR, GSCF), one of the main supply chain focuses is relationships with suppliers in procurement processes ${ }^{6}$. History shows that suppliers can be a source of serious supply risks which can result in severe losses for manufacturing systems ${ }^{7}$. In light of this observation, the article focuses on building resilience in relationships with suppliers, with particular attention on the B2B market.

Structural models play a very important role in management sciences, the verification of which enables the confirmation of theoretical assumptions and statistically important relationships between individual constructs. Although over the last 15 years the topic of SCRES has been present in hundreds of articles, there is still an important research gap regarding its detailed measurement ${ }^{8}$. The inspection of the literature carried out in this paper allowed the identification of more than twenty works presenting a systematic literature review (SLR) on SCRES. Some are based on a review of over 200 publications $^{9}$. Nevertheless, no SLR article addresses the issue of how to measure the resilience in individual areas of the supply chain

a systematic review and paths for further investigation, "International Journal of Physical Distribution Logistics Management" 2015, vol. 45, no. 1/2, pp. 90-117.

4 J.T. Mentzer et al., Defining Supply Chain Management, "Journal of Business Logistics" 2001, vol. 22, no. 2, pp. 1-25.

5 A. Norrman, U. Jansson, Ericsson's proactive supply chain risk management approach after a serious sub-supplier accident, "International Journal of Physical Distribution Logistics Management" 2004, vol. 34, no. 5, pp. 434-456.

6 D.M. Lambert, M.C. Cooper, Issues in supply chain management, "Industrial Marketing Management" 2000, vol. 29, no. 1, pp. 65-83; Supply Chain Council, Supply Chain Operations Reference Model, 2012, revision 11.0.

7 S. Chopra, M.S. Sodhi, Supply-chain breakdown, "MIT Sloan Management Review" 2004, vol. 46, no. 1, pp. 53-61; A. Norrman, U. Jansson, Ericsson's proactive...; D. De Waart, Getting Smart, "Supply Chain Management Review" 2006, vol. 10, no. 8, pp. 27-33.

8 N.O. Hohenstein et al., Research on the phenomenon of supply chain resilience...; M.M.H. Chowdhury, M. Quaddus, Supply chain readiness, response and recovery for resilience, "Supply Chain Management: An International Journal" 2016, vol. 21, no. 6, pp. 709-731.

9 E.g. C.G. Kochan, D.R. Nowicki, Supply chain resilience: a systematic literature review and typological framework, "International Journal of Physical Distribution Logistics Management” 2018, vol. 48, no. 8, pp. 842-865. 
with regard to the main SCRES elements, which are flexibility and redundancy. Instead, the focused on other measurement threads. Hohenstein et al. concluded that SCRES can be assessed with the use of three key performance indicators, which are: customer service, market share and financial performance ${ }^{10}$. Karl et al. researched the influence of non-financial indicators (e.g. supplier delivery efficiency) on supply chain resilience ${ }^{11}$. Other authors measured the loss in performance after a disruption and the time needed to recover from disruption for SCRES ${ }^{12}$. Kamalahmadi and Parast, based on past articles, held a discourse on measuring SCRES with regard to supply chain structure (e.g. density, complexity) and various indexes to evaluate supply chain capabilities ${ }^{13}$. Finally, Chowdhury and Quaddus proposed a SCRES measurement model for disruption phases ${ }^{14}$. However, the proposed constructs were built with regard to the whole supply chain idea.

Given the gap in the literature revealed, the purpose of this paper is to frame the proposal of supply chain resilience measurement for flexibility and redundancy practices in the area of relationships with suppliers. The presented approach is the first version of the framework as at the next stage this proposition requires statistical verification. The starting point for the following research is the observation that adequate flexibility and redundancy practices reduce the number of supply disruptions ${ }^{15}$.

The manuscript makes three specific contributions to the literature. First, it presents the importance of flexibility and redundancy in relationships with suppliers when building supply chain resilience. Next, it lists the flexibility and redundancy practices recommended for strengthening supply chain resilience. Finally, it attempts to propose flexibility and redundancy measurement for resilient cooperation with suppliers. For this purpose, 33 measurable items are presented in four separate constructs (Figure 6).

In order to achieve the research goal, a two-phase methodology design was used. This consists of a literature review and in-depth interviews (IDIs). Section 2 of this paper explains the methodology utilized to perform this literature review.

10 N.O. Hohenstein et al., Research on the phenomenon of supply chain resilience...

11 A.A. Karl et al., Supply chain resilience and key performance indicators: a systematic literature review, "Production" 2018, vol. 28.

12 B.R. Tukamuhabwa et al., Supply chain resilience...

13 M. Kamalahmadi, M.M. Parast, A review of the literature on the principles of enterprise and supply chain resilience: Major findings and directions for future research, "International Journal of Production Economics" 2016, vol. 171, pp. 116-133.

14 M.M.H. Chowdhury, M. Quaddus, Supply chain readiness...

15 G.A. Zsidisin, S.M. Wagner, Do perceptions become reality? The moderating role of supply chain resiliency on disruption occurrence, "Journal of Business Logistics" 2010, vol. 31, no. 2, pp. 1-20. 
Due to the high number of articles presenting the issue of resilience which have appeared in recent years, it was decided to focus attention primarily on the numerous publications presenting SLR on SCRES and then on the cited publications that combine flexibility, redundancy and resilience issues. This approach allowed a comprehensive view of past studies and avoided a duplication of previous analyzes. It also made it possible to access the most relevant articles that deal with flexibility and redundancy practices and to identify key measures with regard to supply chain resilience. The literature findings are discussed in Section 3. Section 4 explains the IDI methodology and collates the results of interviews. Finally, in the last part of this paper SCRES measurement frameworks are discussed from the perspective of flexibility and redundancy in relationships with suppliers as well as their implications and conclusions.

\section{Methodology}

The desk-based research followed the methodology applied by Tranfield, Denyer, and Smart as well as Kamalahmadi and Parast ${ }^{16}$. The analysis of the literature on the subject was carried out in April 2019. The review process (Figure 1) consisted of the following phases: questions formulation, keyword search in databases, screening phases (data collection and data refinement) and analysis of articles. Primarily, it was focused on identifying articles presenting SLR on SCRES and then attempting to find answers to the following questions:

- What is the understanding of flexibility and redundancy in the context of supply chain resilience strategies?

- What are the resilient practices for building flexibility and redundancy in supply chains?

- How has flexibility and redundancy been measured so far in the studies related to the SCRES concept?

- What are the best resilient practices for building flexibility and redundancy in relationships with suppliers?

In the second phase, the author used five research databases, i.e., EBSCOhost Online Research Databases, Emerald Insight, Scopus, Web of Science and Wiley Online Library. These were chosen as they are the leading global providers of top articles evaluated using a double blind peer review policy. This ensured the highest quality of the literature research. Three search terms and the following restrictions were used in the phase of the databases search:

16 D. Tranfield, D Denyer, P. Smart, Towards a methodology for developing evidence-informed management knowledge by means of systematic review, "British Journal of Management" 2003 , vol. 14, no. 3, pp. 207-222; M. Kamalahmadi, M.M. Parast, A review of the literature... 
- Search term: SYSTEMATIC LITERATURE REVIEW, restriction: occurrence in title OR abstract AND

- Search term: SUPPLY CHAIN, restriction: occurrence in abstract AND

- Search term: RESILIENCE OR RESILIENT, restriction: occurrence in abstract.

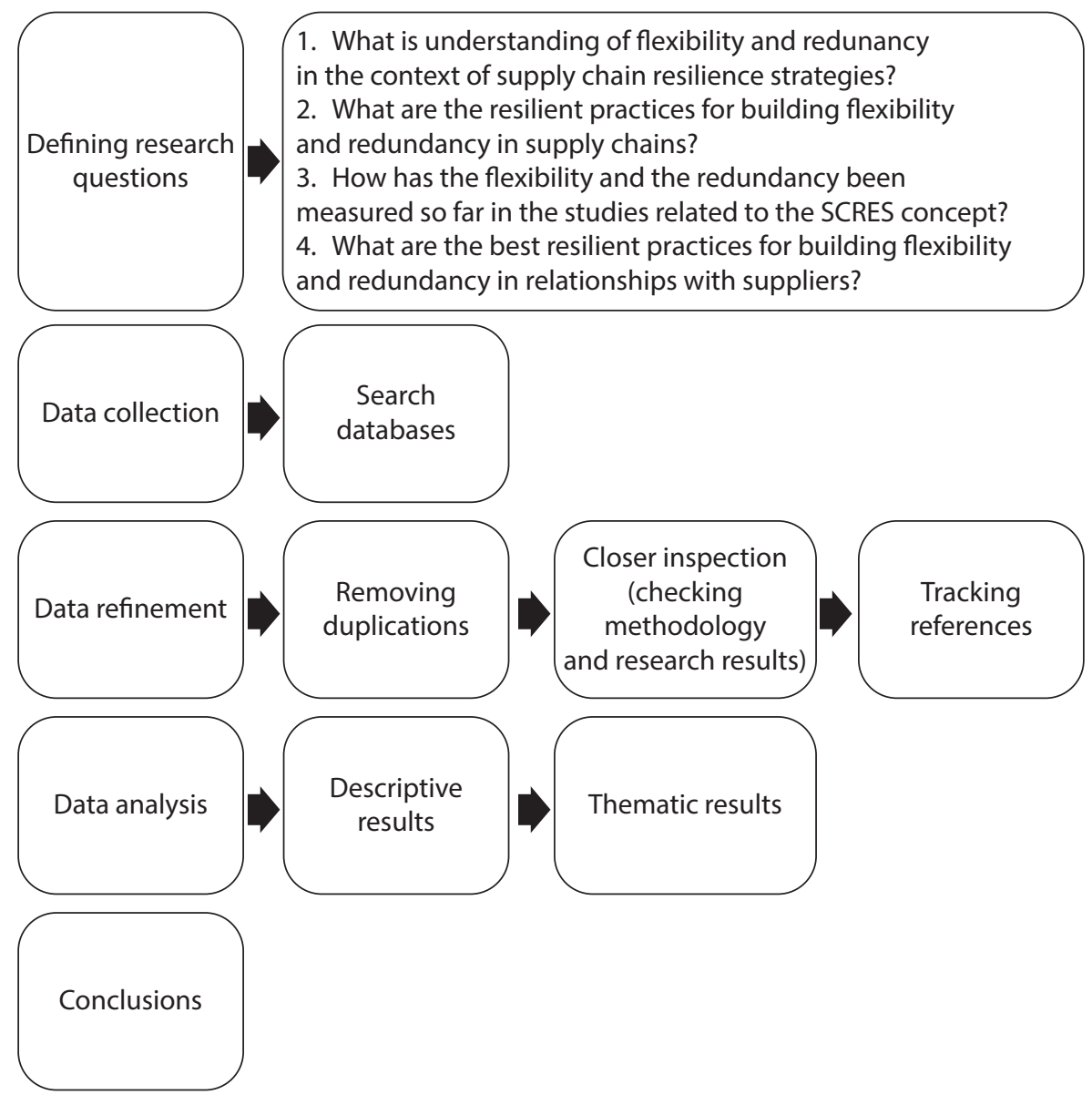

Figure 1. Research process

Source: own study.

There was no restriction on the date of publication in order to identify as many articles presenting the results of a systematic literature review on SCRES as possible.

The first database search resulted in 46 publications. After removing duplicates, 23 articles were selected (Table 1). In the second screening phase, eighteen full papers presenting a systematic literature review on SCRES with particular regard to flexibility and redundancy were identified. These were published between 2009 and March 2019 (Figure 3). The third screening stage consisted of two levels: 
choosing cited articles from these publications that presented SLR on SCRES as well as tracking references in the cited articles (Figure 2). In this two-level (3a and $3 \mathrm{~b}$ ) step, an additional 21 publications were recognized and directed to the final analysis (Figure 1). These were published between 1996 and 2015 years (Figure 4).

Table 1. The screening phase results

\begin{tabular}{|l|l|c|}
\hline \multicolumn{1}{|c|}{ Phase description } & \multicolumn{1}{|c|}{ Database } & Output (number of papers) \\
\hline \multirow{2}{*}{$\begin{array}{l}\text { First database search with the use } \\
\text { of two main search terms }\end{array}$} & EBSCOhost & 9 \\
\cline { 2 - 3 } & Emerald & 13 \\
\cline { 2 - 3 } & Scopus & 15 \\
\cline { 2 - 3 } & Web of Science & 0 \\
\cline { 2 - 3 } & Wiley Online Library & 23 \\
\hline Screening 1: removing duplicates & $\begin{array}{l}\text { EBSCOhost, Emerald, } \\
\text { Scopus, Web of Science, } \\
\text { Wiley Online Library }\end{array}$ & \\
\hline $\begin{array}{l}\text { Screening 2: closer inspection } \\
\text { (selecting articles that pay } \\
\text { special attention to flexibility and } \\
\text { redundancy issues) }\end{array}$ & $\begin{array}{l}\text { EBSCOhost, Emerald, } \\
\text { Scopus, Web of Science, } \\
\text { Wiley Online Library }\end{array}$ & \\
\hline $\begin{array}{l}\text { Screening 3a and 3b (two levels): } \\
\text { checking cited publications } \\
\text { that directly refer to flexibility } \\
\begin{array}{l}\text { and redundancy practices and } \\
\text { measures }\end{array}\end{array}$ & $\begin{array}{l}\text { EBSCOhost, Emerald, } \\
\text { Scopus, Web of Science, } \\
\text { Wiley Online Library }\end{array}$ & $\mathbf{3 9}$ \\
\hline
\end{tabular}

Source: own study.

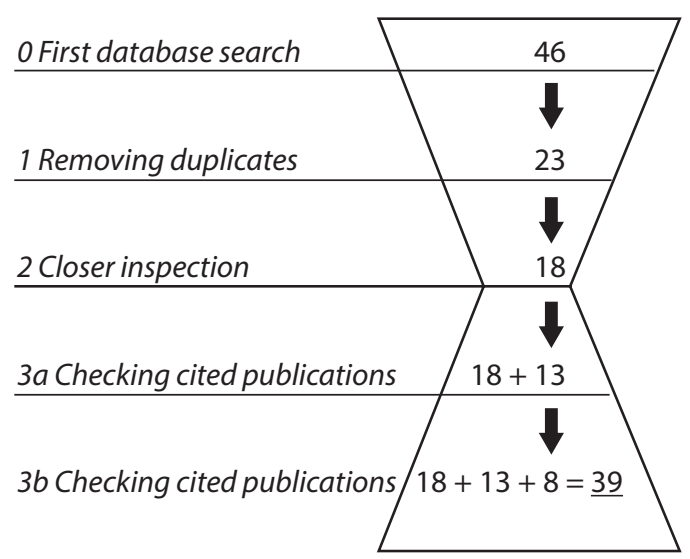

Figure 2. The hourglass publication search process in detail

Source: own study. 


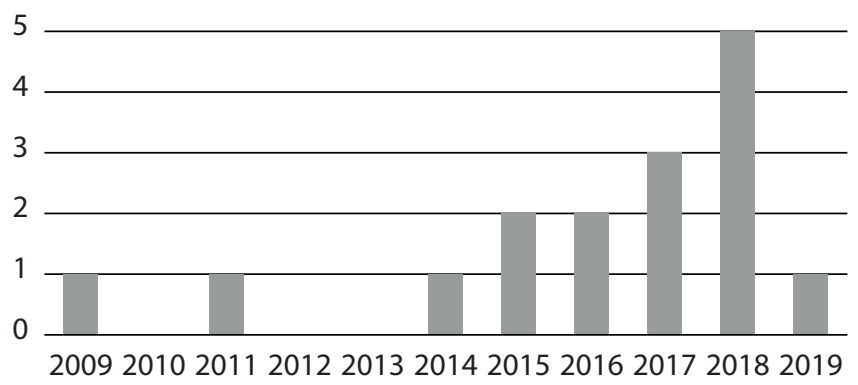

Figure 3. Year-wise distribution of publications presenting SLR on SCRES (output from screening 1 and 2)

Source: own study.

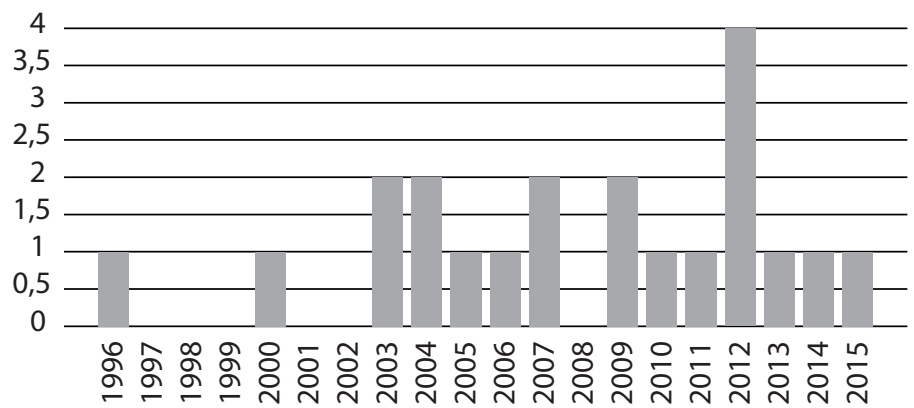

Figure 4. Year-wise distribution of cited publications (output from screening $3 \mathrm{a}$ and 3b)

Source: own study.

The presented review of the literature led to the selection of 39 articles that provide key knowledge on the role of flexibility and redundancy in relationships with suppliers in building supply chain resilience as well as practices and measures for this area.

\section{Flexibility and redundancy - definitions, practices and measures in the review papers concerning the SCRES concept}

Pereira, Christopher, and Lago Da Silva pointed out that flexibility is the predominant theme in past SCRES literature ${ }^{17}$. They also recognized that both flexibility and redundancy are also key SCRES enablers. Furthermore, in their paper it was noted that lack of flexibility is a serious barrier to building resilience in the area

17 C.R. Pereira, M. Christopher, A. Lago Da Silva, Achieving supply chain resilience... 
of supplies and procurement. Based on the literature, the authors distinguished the following types of supply chain flexibility: sourcing flexibility, product flexibility, process flexibility and transportation flexibility. Finally, they recognized that redundancy should be used primarily in relation to critical components.

Hohenstein et al. recognized that flexibility and redundancy are key elements at every stage of SCRES, i.e.: readiness, response, recovery and growth ${ }^{18}$. Based on their systematic literature review, they listed the following sub-elements of redundancy: production slack, transportation capacities, multiple sourcing and production locations. Redundancy is mainly regarded as an element of a proactive strategy, while flexibility belongs to both proactive and reactive strategies and is related to backup suppliers, easy supplier switching, distribution channels, flexible production systems, volume flexibility and multi-skilled workforces.

Other authors made slightly different observations. Tukamuhabwa et al. found that flexibility is both a proactive and reactive resilience strategy, while redundancy is more of a reactive one ${ }^{19}$. They found that flexibility is related to the ability to adapt to changing requirement using flexible contracts, postponement strategies, a multi-skilled labor force or multi-purpose machines, whereas redundancy concerns duplication of resources and possessing alternative opportunities, e.g. additional capacity and inventory. In addition, the authors concluded that some flexibility practices are similar to redundancy practices. For example, multiple sourcing can be regarded as a source of flexibility as well as redundancy.

Karl et al. described flexibility and redundancy as constituent elements during the disruption phase ${ }^{20}$. They focused on the identification of key performance indicators (KPIs) related to the SCRES elements. Following previous studies, they stated that the KPIs related to flexibility are: capacity utilization, on-time delivery of goods, order lead time and delivery lead time, whereas the main redundancy KPI is stock level. Interestingly, Stone and Rahimifard observed that flexibility and redundancy are core elements of a readiness strategy, both in terms of organizational and supply chain resilience ${ }^{21}$. Finally, Chowdhury and Quaddus developed a research model in which both flexibility and redundancy are measurement dimensions related to supply chain readiness ${ }^{22}$. The authors distinguished produc-

18 N.O. Hohenstein et al., Research on the phenomenon of supply chain resilience...

19 B.R. Tukamuhabwa et al., Supply chain resilience...

20 A.A. Karl et al., Supply chain resilience...

21 J. Stone, S. Rahimifard, Resilience in agri-food supply chains: A critical analysis of the literature and synthesis of a novel framework, "Supply Chain Management: An International Journal" 2018, vol. 23, no. 3, pp. 207-238.

22 M.M.H. Chowdhury, M. Quaddus, Supply chain readiness... 
tion flexibility, sourcing flexibility as well as distribution flexibility. In this way covering the processes of the entire supply chain.

The main result of the study performed by Kamalahmadi and Parast ${ }^{23}$ was a supply chain resilience framework established on the four principles demonstrated by Christopher and Peck, with variables assigned to each of them ${ }^{24}$ : flexibility and redundancy (for the reengineering principle), trust and information sharing (for collaboration), visibility and velocity (for agility), leadership and innovation (for the supply chain risk management culture). Kamalahmadi and Parast found that the elements of flexibility and redundancy play a critical role in mitigating any negative effects of disruptions ${ }^{25}$.

Ali, Mahfouz, and Arisha, based on a literature analysis of the subject, designed a SCRES structure in the form of a pyramid ${ }^{26}$. There are three phases at the summit of this framework: pre-disruption, during disruption and post disruption. Each of them requires an appropriate strategy: a proactive, concurrent or reactive one. The framework suggests building five capabilities (the ability to anticipate, to adapt, to respond, to recover, to learn) to perform all three strategies. Underneath the capabilities there are SCRES elements which consist of specific practices. The 'flexibility' element and 'redundancy' elements are listed only for the concurrent strategy and only then for the ability to adapt. Interestingly, Ali, Mahfouz, and Arisha as well as Shin and Park demonstrated that the top SCRES element is the supply chain network design ${ }^{27}$, followed by flexibility and then redundancy. Among the flexibility practices Ali, Mahfouz, and Arisha distinguished supply flexibility, multiple suppliers and flexible transportation mode 28 . Additionally, the authors stated that building redundancy in the area of relationships with suppliers is mainly based on having multiple suppliers, safety stock and strategic inventory.

It is recognized that Datta provided the latest definition of SCRES, based on previous studies:

[...] supply chain resilience is a dynamic process of steering the actions so that the organisation always stays out of danger zone, and if the disruptive/uncertain event

23 M. Kamalahmadi, M.M. Parast, A review of the literature...

24 M. Christopher, H. Peck, Building the resilient...

25 M. Kamalahmadi, M.M. Parast, A review of the literature...

26 Ibidem.

27 A. Ali, A. Mahfouz, A. Arisha, Analysing supply chain resilience...; N. Shin, S. Park, EvidenceBased Resilience Management for Supply Chain Sustainability: An Interpretive Structural Modelling Approach, "Sustainability" 2019, vol. 11, no. 2, p. 484.

28 A. Ali, A. Mahfouz, A. Arisha, Analysing supply chain resilience... 
occurs, resilience implies initiating a very rapid and efficient response to minimise the consequences and maintaining or regaining a dynamically stable state, which allows it to adapt operations to the requirements of the changed environment before the competitors and succeed in the long run ${ }^{29}$.

The author also based his work on a document prepared by MIT Center for Transportation and Logistics. This document shows various resilient practices which are related to flexibility and redundancy. Flexibility is understood hear as "creating capabilities in the firm's organization to respond by using existing capacity that can be redirected or reallocated", while redundancy is explained as:

[...] maintaining capacity in the firm to respond, largely through investments in capital and capacity prior to the point of need. An important distinction is that the additional capacity may or may not be used - it is this additional capacity that would be used to replace the capacity loss of a disruption ${ }^{30}$.

Kochan and Nowicki noted that some authors regard flexibility as a dimension of agility or use both these terms interchangeably ${ }^{31}$. Moreover, there are studies which include redundancy as a dimension of flexibility. Considerations leading to the conclusion that flexibility and redundancy are responsiveness factors are also addressed.

In the latest articles the newest definitions can also be found. Lima et al., based on previous papers, built the following definitions of the main SCRES enablers ${ }^{32}$ :

- flexibility is "the ability of a firm and supply chain to sense threats and react and adapt to changing requirements with minimum time, effort, cost and performance drop";

- redundancy is "the replication/addition of capacity and/or resources that can be invoked during a disturbance to replace the loss of capacity and/or resources during a disturbance”.

29 P. Datta, Supply network resilience: a systematic literature review and future research, "The International Journal of Logistics Management" 2017, vol. 28, no. 4, pp. 1387-1424.

30 MIT Center for Transportation and Logistics, Supply Chain Response to Terrorism: Creating Resilient and Secure Supply Chains, Interim Report of Progress and Learnings, August 8, 2003, http://webcache.googleusercontent.com/search?q=cache:zINMDk6KS3MJ:web.mit .edu/scresponse/repository/SC_Resp_Report_Interim_Final_8803.pdf+\&cd=1\&hl=pl\&ct $=c l n k \& g l=p l \& c l i e n t=$ firefox-b-d (accessed: 5.09 .2020$)$.

31 C.G. Kochan, D.R. Nowicki, Supply chain resilience...

32 F.R.P.D. Lima et al., Systematic review: resilience enablers to combat counterfeit medicines, "Supply Chain Management: An International Journal" 2018, vol. 12, no. 3, p. 126. 
- Similar definitions, were developed by Stone and Rahimifard ${ }^{33}$ :

- flexibility is "the ability of an organisation to adapt with minimum time and effort. Concerns the ability to switch suppliers, substitute ingredients, outsource processes, share materials and staff between sites, the ability of staff to fulfil multiple roles and the levels of control over market position";

- redundancy "concerns the ability to alternate production capacity and to call upon surplus raw materials and finished inventory".

The identified papers discuss not only the definitions but also resilient practices concerning flexibility and redundancy. A number of them directly refer to the area of supplier relationship management (Table 2).

Table 2. Examples of flexibility and redundancy practices in papers presenting SLR on SCRES

\begin{tabular}{|l|l|l|l|}
\hline \multicolumn{1}{|c|}{ Authors } & \multicolumn{1}{|c|}{$\begin{array}{c}\text { Flexibility } \\
\text { and redundancy } \\
\text { in the SCRES concept }\end{array}$} & \multicolumn{1}{|c|}{$\begin{array}{c}\text { Supply chain flexibility } \\
\text { practices }\end{array}$} & \multicolumn{1}{c|}{$\begin{array}{c}\text { Supply chain } \\
\text { redundancy practices }\end{array}$} \\
\hline $\begin{array}{l}\text { Hohenstein } \\
\text { et al. (2015) }\end{array}$ & $\begin{array}{l}\text { Flexibility and } \\
\text { redundancy are key } \\
\text { elements at every } \\
\text { stage of SCRES: } \\
\text { readiness, response, } \\
\text { recovery and growth }\end{array}$ & $\begin{array}{l}\text { Backup suppliers, easy } \\
\text { supplier switching, } \\
\text { distribution channels, } \\
\text { flexible production } \\
\text { systems, volume flexibility, } \\
\text { multi-skilled workforces }\end{array}$ & $\begin{array}{l}\text { Production slack, } \\
\text { transportation } \\
\text { capacities, multiple } \\
\text { sourcing and production } \\
\text { locations }\end{array}$ \\
\hline $\begin{array}{l}\text { Tukamuhabwa } \\
\text { et al. (2015) }\end{array}$ & $\begin{array}{l}\text { Flexibility is both } \\
\text { a proactive and } \\
\text { reactive resilience } \\
\text { strategy, while } \\
\text { redundancy } \\
\text { is a reactive one }\end{array}$ & $\begin{array}{l}\text { Flexible contracts, } \\
\text { postponement strategy, } \\
\text { multi-skilled labour force } \\
\text { or multi-purpose machines }\end{array}$ & $\begin{array}{l}\text { Duplication of resources } \\
\text { and keeping alternative } \\
\text { options, e.g. spare } \\
\text { capacity and inventory }\end{array}$ \\
\hline $\begin{array}{l}\text { Chowdhury, } \\
\text { Quaddus } \\
\text { (2016) }\end{array}$ & $\begin{array}{l}\text { Flexibility and } \\
\text { redundancy are } \\
\text { measurement } \\
\text { dimensions related } \\
\text { to supply chain } \\
\text { readiness }\end{array}$ & $\begin{array}{l}\text { Production flexibility, } \\
\text { customization, multi- } \\
\text { skilled workforce, contract } \\
\text { flexibility, sourcing } \\
\text { flexibility, distribution } \\
\text { flexibility }\end{array}$ & $\begin{array}{l}\text { Reserve capacity, stock, } \\
\text { back-up utility }\end{array}$ \\
\hline $\begin{array}{l}\text { Kamalahmadi, } \\
\text { Parast (2016) }\end{array}$ & $\begin{array}{l}\text { Flexibility and } \\
\text { redundancy play } \\
\text { an important role } \\
\text { ruring supply chain } \\
\text { reengineering }\end{array}$ & $\begin{array}{l}\text { Flexible transportation } \\
\text { systems, flexible } \\
\text { production, facilities, } \\
\text { flexible supply base, } \\
\text { flexible capacity, flexible } \\
\text { labour arrangements }\end{array}$ & $\begin{array}{l}\text { Multiple suppliers, } \\
\text { safety stock, over } \\
\text { capacity, back } \\
\text { up suppliers }\end{array}$ \\
\hline
\end{tabular}

33 J. Stone, S. Rahimifard, Resilience in agri-food supply chains..., p. 220. 
Table 2 (continued)

\begin{tabular}{|c|c|c|c|}
\hline Authors & $\begin{array}{c}\text { Flexibility } \\
\text { and redundancy } \\
\text { in the SCRES concept }\end{array}$ & $\begin{array}{l}\text { Supply chain flexibility } \\
\text { practices }\end{array}$ & $\begin{array}{l}\text { Supply chain } \\
\text { redundancy practices }\end{array}$ \\
\hline $\begin{array}{l}\text { Ali, Mahfouz, } \\
\text { Arisha (2017) }\end{array}$ & $\begin{array}{l}\text { Flexibility and } \\
\text { redundancy are } \\
\text { elements of the } \\
\text { ability to adapt } \\
\text { in a concurrent } \\
\text { strategy }\end{array}$ & $\begin{array}{l}\text { Flexible supply via } \\
\text { multiple suppliers, flexible } \\
\text { manufacturing, processes } \\
\text { or resources, flexible } \\
\text { product via postponement, } \\
\text { flexible pricing via } \\
\text { responsive pricing, flexible } \\
\text { transportation, mode, } \\
\text { flexible order fulfilment }\end{array}$ & $\begin{array}{l}\text { Excess capacity } \\
\text { in production } \\
\text { or transportation } \\
\text { or resources, multiple } \\
\text { suppliers, safety stock, } \\
\text { strategic inventory, } \\
\text { emergency, backup/ } \\
\text { storage facilities, low } \\
\text { capacity utilisation }\end{array}$ \\
\hline $\begin{array}{l}\text { Zhao, Liu, } \\
\text { Lopez (2017) }\end{array}$ & $\begin{array}{l}\text { Flexibility and } \\
\text { redundancy are } \\
\text { complementary } \\
\text { SCRES enablers }\end{array}$ & \multicolumn{2}{|c|}{$\begin{array}{l}\text { Multiple suppliers, multiple transportation channels, } \\
\text { flexible supply base }\end{array}$} \\
\hline $\begin{array}{l}\text { Stone, } \\
\text { Rahimifard } \\
(2018)\end{array}$ & $\begin{array}{l}\text { Flexibility and } \\
\text { redundancy are } \\
\text { core elements } \\
\text { of a readiness } \\
\text { strategy }\end{array}$ & $\begin{array}{l}\text { Switching suppliers, } \\
\text { substitute ingredients, } \\
\text { outsource processes, } \\
\text { share materials and staff } \\
\text { between sites, staff able } \\
\text { to fulfil multiple roles and } \\
\text { exert the levels of control } \\
\text { over market position, } \\
\text { having alternative } \\
\text { options achieved through } \\
\text { partnerships, moving staff } \\
\text { and equipment rapidly }\end{array}$ & $\begin{array}{l}\text { Alternating production } \\
\text { capacity, calling upon } \\
\text { surplus raw materials } \\
\text { and finished inventory }\end{array}$ \\
\hline
\end{tabular}

Source: own study.

In some cases, flexibility practices are identical to redundancy practices. For example, multi-sourcing applies to both categories. When considering the newest definitions of flexibility and redundancy it can be deduced that multi-sourcing means the ability to switch orders between suppliers in terms of flexibility, whereas in the case of redundancy it is about the replication of supply base resources and keeping reserve capacity ${ }^{34}$.

The examined papers cover both quantitative and qualitative research. Past studies used both survey and case study methods. Several authors introduced constructs to measure different types of supply chain flexibility and redundancy (Table 3).

34 F.R.P.D. Lima et al., Systematic review...; J. Stone, S. Rahimifard, Resilience in agri-food supply chains... 
Table 3. Examples of flexibility or redundancy measurements in past studies

\begin{tabular}{|c|c|c|c|c|}
\hline Authors & Methodology & $\begin{array}{c}\text { Name } \\
\text { of element }\end{array}$ & $\begin{array}{c}\text { Measurement } \\
\text { approach }\end{array}$ & Research result \\
\hline $\begin{array}{l}\text { Chang et al. } \\
(2003)\end{array}$ & $\begin{array}{l}\text { Quantitative } \\
\text { study, survey } \\
\text { among } 87 \text { firms } \\
\text { from machinery } \\
\text { and machine tool } \\
\text { industries in Taiwan }\end{array}$ & $\begin{array}{l}\text { Manufacturing } \\
\text { flexibility } \\
\text { (company } \\
\text { as supplier) }\end{array}$ & $\begin{array}{l}\text { Construct defined } \\
\text { by } 6 \text { items } \\
\text { Likert scale } 1-7\end{array}$ & $\begin{array}{l}\text { Compatibility } \\
\text { between business } \\
\text { strategy and manu- } \\
\text { facturing flexibility } \\
\text { is critical to busi- } \\
\text { ness performance }\end{array}$ \\
\hline $\begin{array}{l}\text { Pujawan } \\
(2004)\end{array}$ & $\begin{array}{l}\text { Case study } \\
\text { (manufacturer } \\
\text { of containers } \\
\text { for cosmetics } \\
\text { products), } \\
\text { conceptual paper }\end{array}$ & $\begin{array}{l}\text { Supply } \\
\text { flexibility }\end{array}$ & \begin{tabular}{|l|} 
Element defined \\
by 10 items \\
Assessment \\
of desired and \\
current score (1-5 \\
scale)
\end{tabular} & $\begin{array}{l}\text { Worksheet for } \\
\text { assessing supply } \\
\text { chain flexibility } \\
\text { consisting of sev- } \\
\text { eral flexibility areas }\end{array}$ \\
\hline $\begin{array}{l}\text { Swafford, } \\
\text { Ghosh, } \\
\text { Murthy (2006) }\end{array}$ & $\begin{array}{l}\text { Cross-industry } \\
\text { survey (postal } \\
\text { questionnaire) } \\
\text { among } 115 \\
\text { companies }\end{array}$ & $\begin{array}{l}\text { Sourcing } \\
\text { flexibility }\end{array}$ & $\begin{array}{l}\text { Construct defined } \\
\text { by } 8 \text { items }\end{array}$ & $\begin{array}{l}\text { Degree of flexibil- } \\
\text { ity present in the } \\
\text { manufacturing and } \\
\text { procurement pro- } \\
\text { cesses positively } \\
\text { influences supply } \\
\text { chain agility }\end{array}$ \\
\hline $\begin{array}{l}\text { Skipper, } \\
\text { Hanna (2009) }\end{array}$ & $\begin{array}{l}\text { Survey among } \\
\text { personnel involved } \\
\text { in advanced } \\
\text { contingency } \\
\text { planning, } 168 \\
\text { questionnaires }\end{array}$ & Flexibility & $\begin{array}{l}\text { Construct defined } \\
\text { by three items } \\
\text { applied from } \\
\text { Fawcett et al. } \\
(1996)\end{array}$ & $\begin{array}{l}\text { Several hypothesis, } \\
\text { e.g. information } \\
\text { technology usage } \\
\text { in the contingency } \\
\text { planning process } \\
\text { is positively related } \\
\text { to flexibility }\end{array}$ \\
\hline $\begin{array}{l}\text { Tachizawa, } \\
\text { Thomsen } \\
\text { (2009) }\end{array}$ & $\begin{array}{l}\text { Cross-industry } \\
\text { survey among } \\
\text { members of the } \\
\text { Spanish Association } \\
\text { of Purchasing } \\
\text { Managers, } 100 \\
\text { questionnaires } \\
\end{array}$ & $\begin{array}{l}\text { Supply } \\
\text { flexibility } \\
\text { sources }\end{array}$ & $\begin{array}{l}\text { Construct defined } \\
\text { by fourteen } \\
\text { practices }\end{array}$ & $\begin{array}{l}\text { Flexibility sources } \\
\text { differently de- } \\
\text { termine supplier } \\
\text { responsiveness, } \\
\text { delivery policy and } \\
\text { adaptability }\end{array}$ \\
\hline
\end{tabular}


Table 3 (continued)

\begin{tabular}{|c|c|c|c|c|}
\hline Authors & Methodology & $\begin{array}{c}\text { Name } \\
\text { of element }\end{array}$ & $\begin{array}{l}\text { Measurement } \\
\text { approach }\end{array}$ & Research result \\
\hline Park (2011) & $\begin{array}{l}\text { Cross-industry } \\
\text { survey among } 163 \\
\text { companies }\end{array}$ & $\begin{array}{l}\text { Measurement } \\
\text { model for } \\
\text { flexible } \\
\text { practices and } \\
\text { measurement } \\
\text { model for } \\
\text { redundancy } \\
\text { practices }\end{array}$ & $\begin{array}{l}\text { Flexible practices } \\
\text { expressed with } \\
\text { several con- } \\
\text { structs: extent } \\
\text { of postpone (3 } \\
\text { items), informa- } \\
\text { tion sharing (4 } \\
\text { items), security } \\
\text { (4 items), extent } \\
\text { of collaboration } \\
\text { (4 items), contin- } \\
\text { gency planning } \\
\text { ( } 3 \text { items) } \\
\text { Redundancy } \\
\text { practices ex- } \\
\text { pressed with two } \\
\text { constructs: safety } \\
\text { stock (4 items), } \\
\text { slack capacity } \\
\text { ( } 3 \text { items) } \\
\text { Likert scale 1-5 }\end{array}$ & $\begin{array}{l}\text { Several hypothesis } \\
\text { related to various } \\
\text { types of risk, } \\
\text { SCRES, flexibility } \\
\text { and redundancy } \\
\text { practices were } \\
\text { confirmed }\end{array}$ \\
\hline $\begin{array}{l}\text { Chiang, } \\
\text { Kocabasoglu- } \\
\text {-Hillmer, } \\
\text { Suresh (2012) }\end{array}$ & $\begin{array}{l}\text { Survey among } \\
\text { members of the } \\
\text { Institute for Supply } \\
\text { Management, } 144 \\
\text { valid questionnaires }\end{array}$ & $\begin{array}{l}\text { Firm's strategic } \\
\text { flexibilities }\end{array}$ & $\begin{array}{l}\text { Area expressed } \\
\text { with three } \\
\text { constructs: sup- } \\
\text { ply flexibility (3 } \\
\text { items), product } \\
\text { design-related } \\
\text { flexibility (3 } \\
\text { items), process- } \\
\text { related flexibility } \\
\text { (4 items). Items } \\
\text { applied follow- } \\
\text { ing four previous } \\
\text { studies } \\
\text { Likert scale 1-5 }\end{array}$ & $\begin{array}{l}\text { Strategic sourcing } \\
\text { and strategic } \\
\text { flexibility are } \\
\text { significantly related } \\
\text { to the firm's supply } \\
\text { chain agility }\end{array}$ \\
\hline
\end{tabular}




\begin{tabular}{|c|c|c|c|c|}
\hline Authors & Methodology & $\begin{array}{c}\text { Name } \\
\text { of element }\end{array}$ & $\begin{array}{c}\text { Measurement } \\
\text { approach }\end{array}$ & Research result \\
\hline $\begin{array}{l}\text { Chu, Chang, } \\
\text { Huang (2012) }\end{array}$ & $\begin{array}{l}\text { Survey among } \\
162 \text { respondents } \\
\text { from the Supply } \\
\text { Management } \\
\text { Institute in Taiwan }\end{array}$ & $\begin{array}{l}\text { Supplier } \\
\text { flexibility }\end{array}$ & \begin{tabular}{|l|} 
Area expressed \\
with four con- \\
structs: volume \\
flexibility (6 \\
items), mix flex- \\
ibility (6 items), \\
new product flex- \\
ibility ( 4 items), \\
delivery flexibility \\
( 5 items). Items \\
applied following \\
seven previous \\
studies. \\
Likert scale $1-5$ \\
\end{tabular} & $\begin{array}{l}\text { Coercive influence } \\
\text { strategies and } \\
\text { shared vision } \\
\text { have a positive } \\
\text { impact on supplier } \\
\text { flexibility. } \\
\text { Supplier flexibility } \\
\text { has a significant } \\
\text { positive } \\
\text { impact on the } \\
\text { performance } \\
\text { of manufacturers }\end{array}$ \\
\hline $\begin{array}{l}\text { Chowdhury, } \\
\text { Quaddus } \\
(2016)\end{array}$ & $\begin{array}{l}\text { Survey performed } \\
\text { among } 272 \\
\text { manufacturing } \\
\text { companies and } \\
\text { their suppliers }\end{array}$ & $\begin{array}{l}\text { Supply chain } \\
\text { flexibility and } \\
\text { redundancy }\end{array}$ & $\begin{array}{l}\text { Supply chain flex- } \\
\text { ibility construct } \\
\text { expressed with } \\
6 \text { items, supply } \\
\text { chain redundancy } \\
\text { expressed with } \\
3 \text { items } \\
\text { Likert scale } 1-6 \\
\end{array}$ & $\begin{array}{l}\text { Constructs were } \\
\text { confirmed. Supply } \\
\text { chain orientation } \\
\text { and supply chain } \\
\text { risk management } \\
\text { culture influence } \\
\text { supply chain } \\
\text { readiness }\end{array}$ \\
\hline
\end{tabular}

Source: own study.

The recognized constructs are an important source of information on resilient practices, measurement approaches as well as the types and number of implemented items. The authors used either a five, six or seven point Likert scale to measure observable variables. Interestingly, Pujawan, based on case studies, created a comprehensive tool for assessing supply chain flexibility 35 .

Analysis of the collected articles shows that flexibility and redundancy are key SCRES determinants. In past studies, these were variously named as, e.g. strategies $^{36}$ or enablers ${ }^{37}$. However, it must be noted that they were predominantly regarded as SCRES elements ${ }^{38}$. This observation concerns especially the latest articles ${ }^{39}$.

35 I.N. Pujawan, Assessing supply chain flexibility: a conceptual framework and case study, "International Journal of Integrated Supply Management" 2004, vol. 1, no. 1, pp. 79-97.

36 B.R. Tukamuhabwa et al., Supply chain resilience...

37 M. Christopher, H. Peck, Building the resilient...

38 N.O. Hohenstein et al., Research on the phenomenon of supply chain resilience...; M. Kamalahmadi, M.M. Parast, A review of the literature...; A. Ali, A. Mahfouz, A. Arisha, Analysing supply chain resilience...

39 A.A. Karl et al., Supply chain resilience...; J. Stone, S. Rahimifard, Resilience in agri-food supply chains...; N. Shin, S. Park, Evidence-Based Resilience Management... 
The authors willingly built SCRES frameworks concerning the time aspect. Two main approaches can be distinguished here. The first is related to the three disruption phases: "before", "during" and "after" the crisis situation ${ }^{40}$. There are papers indicating flexibility and redundancy as important elements for each disruption phase ${ }^{41}$. The second approach concerns proactive and reactive strategies. Some scientists attribute flexibility and redundancy only to one strategy ${ }^{42}$, whereas other authors to more than one strategy ${ }^{43}$. Taking into account all frameworks, both flexibility and redundancy should be present at each SCRES stage, but the context varies depending on the disruption phase (Figure 5).

Before supply chain disruption occurs, it is important to prepare and plan activities that would mitigate any negative risk consequences. During crisis situations, previously designed flexibility and redundancy capabilities are utilized to respond to adverse events and prevent the domino effect efficiently. After disruption, when the supply chain has obtained its previous or new homeostasis, a lesson should be learned and, if necessary, flexibility and redundancy should be re-designed along the idea of continuous improvement.

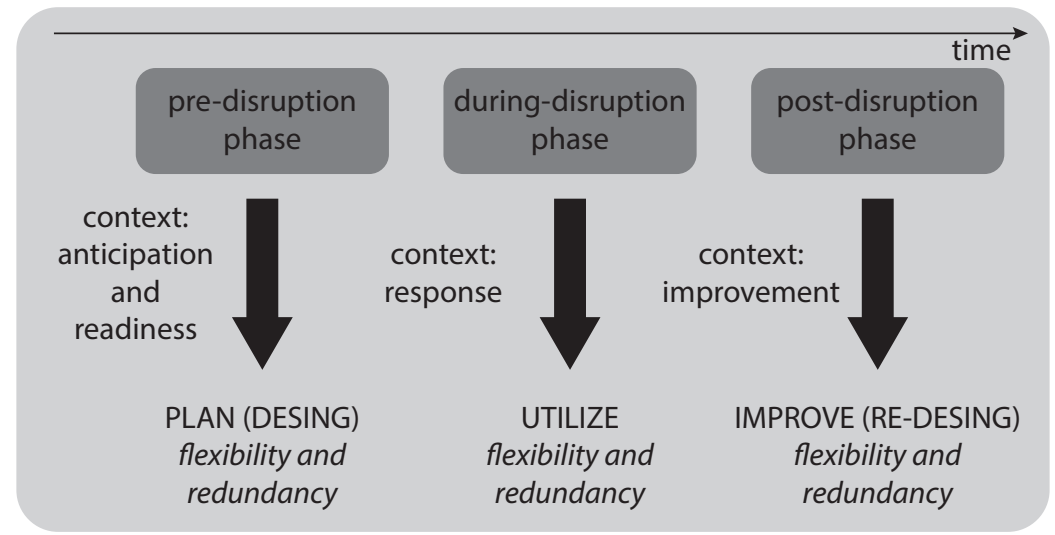

Figure 5. The context of flexibility and redundancy in the three disruption phases

Source: own study.

40 A. Ali, A. Mahfouz, A. Arisha, Analysing supply chain resilience...

41 N.O. Hohenstein et al., Research on the phenomenon of supply chain resilience...; A.A. Karl et al., Supply chain resilience...

42 J. Stone, S. Rahimifard, Resilience in agri-food supply chains...

43 B.R. Tukamuhabwa et al., Supply chain resilience... 


\section{In depth interviews}

One of the objectives of the study was to gather information on how manufacturing companies understand ensuring flexibility and redundancy in their relationships with suppliers. Therefore, eight in-depth interviews were conducted. The respondents were primarily purchasing managers and CEOs employed in medium and large manufacturing companies operating in the B2B market in Poland (one researched company was small). The main criterion for the company's selection was whether the enterprise recognizes and performs supplier relationship management. Each company represents a different sector, which are: audio and visual devices, pharmaceutical, automotive, household goods, clothing, food, electronics or cosmetics (Table 4). This allowed for more comprehensive results to be collected. All companies offer products for both domestic and foreign market.

The interviews allowed the identification of various practices that enhance resiliency in relationships with suppliers. These practices are in line with those indicated in the theory. The flexibility practices highlighted by the companies can be divided into those related to flexible sourcing or supplier flexibility (Table 5).

The interviewed enterprises often decide to implement double or multi-sourcing. Shifting orders is facilitated by short-term contracts and the implementation of advanced IT tools. It is evident that, depending on the type of item purchased, companies decide to develop sourcing flexibility or to cooperate with flexible suppliers. The second situation usually concerns strategic and bottlenecks items. In this case, it is particularly important to build partnerships based on trust and information sharing. In the face of sole sourcing, companies try to sign both a flexible and, if possible, long-term contract.

Table 4. Characteristics of the researched companies

\begin{tabular}{|c|l|l|c|c|c|c|}
\hline $\begin{array}{c}\text { Inter- } \\
\text { view } \\
\text { no. }\end{array}$ & Industry & $\begin{array}{c}\text { Position of the } \\
\text { respondent(s) }\end{array}$ & $\begin{array}{c}\text { No. } \\
\text { of em- } \\
\text { ployees }\end{array}$ & Capital & Spatial range & $\begin{array}{l}\text { Products offe- } \\
\text { red on a speci- } \\
\text { fic market }\end{array}$ \\
\hline 1 & $\begin{array}{l}\text { Audio and } \\
\text { visual } \\
\text { devices }\end{array}$ & $\begin{array}{l}\text { Senior Purchasing } \\
\text { Buyer }\end{array}$ & 289 & foreign & international & $\begin{array}{l}\text { domestic and } \\
\text { foreign }\end{array}$ \\
\hline 2 & $\begin{array}{l}\text { Pharma- } \\
\text { ceutical }\end{array}$ & $\begin{array}{l}\text { Head of Purchasing } \\
\text { and Logistics } \\
\text { Department and } \\
\text { one employee }\end{array}$ & 111 & foreign & national & $\begin{array}{l}\text { domestic and } \\
\text { foreign }\end{array}$ \\
\hline 3 & Automotive & $\begin{array}{l}\text { Supplier } \\
\text { Development } \\
\text { Manager }\end{array}$ & 520 & foreign & international & $\begin{array}{l}\text { domestic and } \\
\text { foreign }\end{array}$ \\
\hline 4 & $\begin{array}{l}\text { Household } \\
\text { goods }\end{array}$ & \begin{tabular}{l} 
Head of Logistics \\
\hline
\end{tabular} & 2283 & national & international & $\begin{array}{l}\text { domestic and } \\
\text { foreign }\end{array}$ \\
\hline
\end{tabular}


Table 4 (continued)

\begin{tabular}{|c|l|l|c|l|l|l|}
\hline $\begin{array}{c}\text { Inter- } \\
\text { view } \\
\text { no. }\end{array}$ & Industry & $\begin{array}{c}\text { Position of the } \\
\text { respondent(s) }\end{array}$ & $\begin{array}{c}\text { No. } \\
\text { of em- } \\
\text { ployees }\end{array}$ & Capital & Spatial range & $\begin{array}{c}\text { Products offe- } \\
\text { red on a speci- } \\
\text { fic market }\end{array}$ \\
\hline 5 & Clothing & CEO & 501 & national & national & $\begin{array}{l}\text { domestic and } \\
\text { foreign }\end{array}$ \\
\hline 6 & Food & $\begin{array}{l}\text { Head of Purchasing } \\
\text { Department }\end{array}$ & 125 & foreign & national & $\begin{array}{l}\text { domestic and } \\
\text { foreign }\end{array}$ \\
\hline 7 & Electronics & CEO & 10 & national & international & $\begin{array}{l}\text { domestic and } \\
\text { foreign }\end{array}$ \\
\hline 8 & $\begin{array}{l}\text { Cosmetics } \\
\text { packaging }\end{array}$ & $\begin{array}{l}\text { Product } \\
\text { development } \\
\text { engineer }\end{array}$ & 2500 & foreign & international & $\begin{array}{l}\text { domestic and } \\
\text { foreign }\end{array}$ \\
\hline
\end{tabular}

Source: own study.

The researched companies pay particular attention to the issue of supplier evaluation. During the preliminary assessment, companies check whether the supplier's production system is sufficiently flexible. Periodic evaluation, on the other hand, enables confirmation of whether the supplier's capacity is sufficient and in line with pre-established requirements. In order to assess the supplier, a second party audit is often implemented.

The results show that companies prefer to conduct activities focused on comprehensive supplier management. Interestingly, there are also organizations which decide to involve suppliers in product development to enhance supply flexibility. Customers often decide to invest a number of resources in this business relationship. For example, they conduct supplier development programs aimed at improvement of the manufacturing system. This practice usually occurs when there is a shortage of suppliers with the appropriate capacities on the market.

Among the identified activities, there are also those concerning redundancy - like safety stock, safety lead time or back-up suppliers. A strategy of indirect purchases supports flexible sourcing and, in some cases, it fulfils the role of redundancy. A back-up supplier is often a distributor located in the same country. Even though it offers a higher price than the producer, it guarantees shorter delivery time, which is especially important in emergency situations. Having an alternative supplier is also relevant to logistics services, where in crisis situations companies most often turn to air transportation. 
Table 5. Flexibility and redundancy practices that are performed by interviewed manufacturers in their relationships with suppliers

\begin{tabular}{|c|c|c|c|}
\hline Practice & $\begin{array}{c}\text { Interview } \\
\text { no. }\end{array}$ & Comment & $\begin{array}{c}\text { Type } \\
\text { of practice }\end{array}$ \\
\hline $\begin{array}{l}\text { Double/multi } \\
\text { sourcing }\end{array}$ & $2,3,4,8$ & $\begin{array}{l}\text { Two or more suppliers of one item. Decision } \\
\text { is based on supplier segmentation. }\end{array}$ & \multirow{13}{*}{$\begin{array}{l}\text { Flexibility } \\
\text { in relation- } \\
\text { ships with } \\
\text { suppliers }\end{array}$} \\
\hline Indirect purchases & 3,6 & Cooperation with distributors. & \\
\hline $\begin{array}{l}\text { Local/domestic } \\
\text { sourcing }\end{array}$ & $1,4,8$ & $\begin{array}{l}\text { Looking for suppliers located nearby } \\
\text { to ensure rapid supplies. }\end{array}$ & \\
\hline Flexible contracts & 3,5 & $\begin{array}{l}\text { Flexibility clauses, short term contracts, } \\
\text { agreements defining the range of possible } \\
\text { changes to orders (e.g. +/- volume). }\end{array}$ & \\
\hline $\begin{array}{l}\text { Preliminary } \\
\text { assessment } \\
\text { ensuring supplier } \\
\text { flexibility }\end{array}$ & $\begin{array}{l}1,2,6 \\
7,8\end{array}$ & $\begin{array}{l}\text { Looking for suppliers of high manufacturing } \\
\text { capabilities, supply flexibility (e.g. volume, } \\
\text { delivery), short lead times. }\end{array}$ & \\
\hline $\begin{array}{l}\text { Periodic assessment } \\
\text { ensuring supplier } \\
\text { flexibility }\end{array}$ & $1,2,6$ & $\begin{array}{l}\text { Evaluating supply responsiveness, supply } \\
\text { flexibility, quality. }\end{array}$ & \\
\hline Audit & $2,3,6,7$ & Second-party audits. & \\
\hline Long term contracts & 2,4 & $\begin{array}{l}\text { Especially in the case of a limited number } \\
\text { of suppliers. }\end{array}$ & \\
\hline Direct purchases & $\begin{array}{l}1,2,3,4 \\
5,6,7\end{array}$ & Supplier is a manufacturer. & \\
\hline $\begin{array}{l}\text { Joint product } \\
\text { development }\end{array}$ & $3,6,7$ & Involving supplier in product development. & \\
\hline $\begin{array}{l}\text { Supplier } \\
\text { development }\end{array}$ & 3 & $\begin{array}{l}\text { Supporting supplier with trainings and } \\
\text { infrastructure investments. }\end{array}$ & \\
\hline IT systems & $\begin{array}{l}3,4,6 \\
7,8\end{array}$ & $\begin{array}{l}\text { Systems (ERP, VMI) are especially important } \\
\text { to aid switching orders between suppliers } \\
\text { and sharing information. }\end{array}$ & \\
\hline Sharing information & 1,2 & $\begin{array}{l}\text { Sharing production plans and forecasts } \\
\text { with suppliers. }\end{array}$ & \\
\hline $\begin{array}{l}\text { Building } \\
\text { partnership }\end{array}$ & $1,4,8$ & $\begin{array}{l}\text { Developing win-win relationships even } \\
\text { in the case of unequal power, cooperation } \\
\text { based on trust and active communication. }\end{array}$ & \\
\hline Logistics flexibility & 1,3 & $\begin{array}{l}\text { The use of air transportation during crisis } \\
\text { situations, cooperation with logistics } \\
\text { providers. }\end{array}$ & \\
\hline Back-up suppliers & $2,3,8$ & $\begin{array}{l}\text { It is not always possible to have alternative } \\
\text { supplier. A back up supplier is often } \\
\text { a distributor located nearby. }\end{array}$ & $\begin{array}{l}\text { Redundancy } \\
\text { in relation- } \\
\text { ships with }\end{array}$ \\
\hline $\begin{array}{l}\text { Safety stocks, safety } \\
\text { lead time }\end{array}$ & $2,3,8$ & Keeping additional stock and time buffers. & suppliers \\
\hline Inventories & $1,2,3,7$ & $\begin{array}{l}\text { Stock sourcing (stock is kept by supplier } \\
\text { or buyer). }\end{array}$ & \\
\hline
\end{tabular}




\section{The measurement framework - flexibility and redundancy in relationships with suppliers}

Based on the results from the literature review and the in-depth interviews, the first proposal of SCRES measurement for the area of supplier relationship management has been developed. It covers four measurable areas: supplier flexibility, procurement flexibility, logistics flexibility and redundancy in supplier-buyer cooperation (Figure 6). Each construct is described with several observable variables which are resilient practices that were recognized in the two-phase qualitative research.

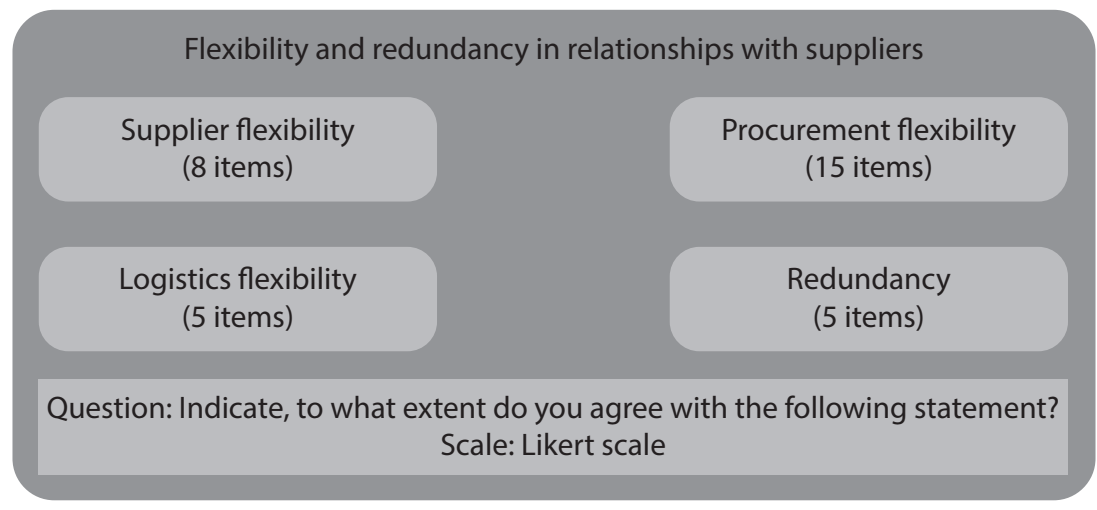

Figure 6. SCRES measurement - the perspective of flexibility and redundancy in relationships with suppliers

Source: own study.

The supply chain flexibility concept is derived from the literature on production flexibility 44 . Product, mix, volume and delivery flexibilities are regarded as key outputs from the flexible manufacturing or distributing systems ${ }^{45}$. Therefore, the first latent variable in the framework is expressed with several items that describe a supplier's abilities to respond to various order changes as well as a sudden increase in demand (Table 6).

44 S.N. Vickery, R. Calantone, C. Dröge, Supply chain flexibility: an empirical study, "Journal of Supply Chain Management” 1999, vol. 35, no. 2, pp. 16-24; R.J. Vokurka, S.W. O'LearyKelly, A review of empirical research on manufacturing flexibility, "Journal of Operations Management” 2000, vol. 18, no. 4, pp. 485-501; S.C. Chang et al., Manufacturing flexibility and business strategy: an empirical study of small and medium sized firms, "International Journal of Production Economics" 2003, vol. 83, no. 1, pp. 13-26; N. Slack, The flexibility of manufacturing systems, "International Journal of Operations Production Management" 2005, vol. 25, no. 12, pp. 1190-1200.

45 D.F. Ross, Supply Chain Performance Measurement, APICS Profession Development, 2010, https://pdf4pro.com/view/supply-chain-performance-measurement-apics-2401b4.html (accessed: 5.09.2020); Supply Chain Council, Supply Chain Operations..., p. 12. 
Table 6. Supplier flexibility - construct proposition

\begin{tabular}{|c|c|c|c|}
\hline No. & Item & References & Interview no. \\
\hline 1 & $\begin{array}{l}\text { Suppliers are able to respond } \\
\text { to volume changes }\end{array}$ & $\begin{array}{l}\text { Chang et al. (2003), Swafford, Ghosh, } \\
\text { Murthy (2006), Tachizawa, Thomsen } \\
\text { (2009), Chu, Chang, Huang (2012) }\end{array}$ & \multirow{7}{*}{$\begin{array}{l}\text { Companies } \\
\text { performing } \\
\text { supplier } \\
\text { assessment } \\
\text { to ensure } \\
\text { supplier } \\
\text { flexibility: } 1,2 \text {, } \\
6,7,8 \\
\text { Companies } \\
\text { performing } \\
\text { second party } \\
\text { audits: } 2,3,6,7\end{array}$} \\
\hline 2 & $\begin{array}{l}\text { Suppliers are able to offer } \\
\text { small minimum order } \\
\text { quantity }\end{array}$ & Pujawan (2004) & \\
\hline 3 & $\begin{array}{l}\text { Suppliers are able to respond } \\
\text { to delivery time changes }\end{array}$ & $\begin{array}{l}\text { Chang et al. (2003), Swafford, Ghosh, } \\
\text { Murthy (2006), Tachizawa, Thomsen } \\
\text { (2009), Chu, Chang, Huang (2012) }\end{array}$ & \\
\hline 4 & $\begin{array}{l}\text { Suppliers are able to produce } \\
\text { a large volume in a short } \\
\text { time }\end{array}$ & \begin{tabular}{|l|} 
Swafford, Ghosh, Murthy (2006), \\
Tachizawa, Thomsen (2009), Chowdhury, \\
Quaddus (2016), Stone, Rahimifard \\
(2018)
\end{tabular} & \\
\hline 5 & $\begin{array}{l}\text { Suppliers are able to respond } \\
\text { to changes in the type } \\
\text { of ordered items }\end{array}$ & $\begin{array}{l}\text { Chang et al. (2003), Pujawan (2004), } \\
\text { Swafford, Ghosh, Murthy (2006), } \\
\text { Tachizawa, Thomsen (2009), Chiang, } \\
\text { Kocabasoglu-Hillmer, Suresh (2012), } \\
\text { Chu, Chang, Huang (2012) }\end{array}$ & \\
\hline 6 & $\begin{array}{l}\text { Suppliers are able to develop } \\
\text { new products }\end{array}$ & $\begin{array}{l}\text { Chang et al. (2003), Chiang, } \\
\text { Kocabasoglu-Hillmer, Suresh (2012), } \\
\text { Chu, Chang, Huang (2012) }\end{array}$ & \\
\hline 7 & $\begin{array}{l}\text { Suppliers are able } \\
\text { to implement engineering } \\
\text { changes to orders }\end{array}$ & \begin{tabular}{|l|} 
Chang et al. (2003), Swafford, Ghosh, \\
Murthy (2006), Tachizawa, Thomsen \\
(2009), Chiang, Kocabasoglu-Hillmer, \\
Suresh (2012), Chu, Chang, Huang (2012)
\end{tabular} & \\
\hline 8 & $\begin{array}{l}\text { Suppliers are able to offer } \\
\text { various pre- and after } \\
\text { services }\end{array}$ & Chang et al. (2003) & \\
\hline
\end{tabular}

Source: own study.

Many authors underline the importance of a flexible supply base to ensure SCRES ${ }^{46}$, usually, stating that enterprises have two alternatives ${ }^{47}$. Companies may cooperate with flexible suppliers (in this case it is suggested to develop partnerships

46 N.O. Hohenstein et al., Research on the phenomenon of supply chain resilience...; M. Kamalahmadi, M.M. Parast, A review of the literature...; A. Ali, A. Mahfouz, A. Arisha, Analysing supply chain resilience...; G. Zhao, S. Liu, C. Lopez, A literature review on risk sources and resilience factors in agri-food supply chains, [in:] L.M. Camarinha-Mathos, H. Afsarmanesh, R. Fornasiero (eds), Working Conference on Virtual Enterprises, Springer, Cham 2017, pp. 739-752.

47 I.N. Pujawan, Assessing supply chain flexibility...; A. Martínez Sánchez, M. Pérez Pérez, Supply chain flexibility and firm performance: a conceptual model and empirical study in the automotive industry, "International Journal of Operations Production Management" 2005, vol. 25, no. 7, pp. 681-700; E.M. Tachizawa, C.G. Thomsen, Drivers and sources of supply flexibility: an exploratory study, "International Journal of Operations Production Management" 2007, vol. 27, no. 10, pp. 1115-1136; A. Ali, A. Mahfouz, A. Arisha, Analysing supply chain resilience... 
and sign long-term contracts $\left.{ }^{48}\right)$. However, it is not always possible to find suppliers with appropriate capabilities. Therefore, an important alternative is to develop procurement flexibility. Gosling, Purvis, and Naim built a matrix showing that close cooperation is related with high vendor flexibility, whereas loose relationship occurs when vendor flexibility is low but sourcing flexibility is high ${ }^{49}$. The proposed approach takes into account both scenarios, since the second construct covers procurement flexibility (Table 7).

Table 7. Procurement flexibility - construct proposition

\begin{tabular}{|c|c|c|c|}
\hline No. & Item & References & \begin{tabular}{|c|}
$\begin{array}{c}\text { Interview } \\
\text { no. }\end{array}$ \\
\end{tabular} \\
\hline 1 & $\begin{array}{l}\text { Buyer performs multi } \\
\text { (or double) sourcing }\end{array}$ & $\begin{array}{l}\text { Pujawan (2004), Tachizawa, Thomsen } \\
\text { (2009), Zsidisin, Wagner (2010), Yi, Ngai, } \\
\text { Moon (2011), Pettit, Croxton, Fiksel (2013), } \\
\text { Tukamuhabwa et al. (2015), Ali, Mahfouz, } \\
\text { Arisha (2017), Zhao, Liu, Lopez (2017), } \\
\text { Stone, Rahimifard (2018) }\end{array}$ & $2,3,4,8$ \\
\hline 2 & $\begin{array}{l}\text { Buyer cooperates with local } \\
\text { (domestic) suppliers }\end{array}$ & Tachizawa, Thomsen (2009) & $1,4,8$ \\
\hline 3 & $\begin{array}{l}\text { The costs incurred in switching } \\
\text { the purchase of item from one } \\
\text { supplier to another is low }\end{array}$ & Pujawan (2004), Hohenstein et al. (2015) & - \\
\hline 4 & $\begin{array}{l}\text { Time required to find/obtain } \\
\text { additional sources is short }\end{array}$ & $\begin{array}{l}\text { Supply Chain Council (2012, p. 66), } \\
\text { Hohenstein et al. (2015) }\end{array}$ & - \\
\hline 5 & $\begin{array}{l}\text { Buyer intensely plans and } \\
\text { shares information with the } \\
\text { suppliers (e.g. about forecasts, } \\
\text { production plans, inventory } \\
\text { levels) }\end{array}$ & $\begin{array}{l}\text { Stevenson, Spring (2007), Tachizawa, } \\
\text { Thomsen (2009), Park (2011) }\end{array}$ & 1,2 \\
\hline 6 & $\begin{array}{l}\text { Buyer develops long-term } \\
\text { relationship with suppliers }\end{array}$ & Tachizawa, Thomsen (2009) & $1,2,4,8$ \\
\hline 7 & $\begin{array}{l}\text { Buyer uses IT planning } \\
\text { tools and/or Electronic Data } \\
\text { Interchange (EDI) in their } \\
\text { relationship with suppliers }\end{array}$ & $\begin{array}{l}\text { Skipper and Hanna (2009), Tachizawa, } \\
\text { Thomsen (2009) }\end{array}$ & $\begin{array}{l}3,4,6 \\
7,8\end{array}$ \\
\hline 8 & $\begin{array}{l}\text { Time required in negotiating } \\
\text { new source/volume contracts/ } \\
\text { terms is short }\end{array}$ & $\begin{array}{l}\text { Tachizawa, Thomsen (2009), Supply Chain } \\
\text { Council (2012, p. 66) }\end{array}$ & - \\
\hline
\end{tabular}

48 L.K. Duclos, R.J. Vokurka, R.R. Lummus, A conceptual model of supply chain flexibility, "Industrial Management Data Systems" 2003, vol. 103, no. 6, pp. 446-456.

49 J. Gosling, L. Purvis, M.M. Naim, Supply chain flexibility as a determinant of supplier selection, "International Journal of Production Economics" 2010, vol. 128, no. 1, pp. 11-21. 


\begin{tabular}{|r|l|l|l|}
\hline No. & \multicolumn{1}{|c|}{ Item } & \multicolumn{1}{|c|}{ References } & \multicolumn{1}{|c|}{$\begin{array}{l}\text { Interview } \\
\text { no. }\end{array}$} \\
\hline 9 & Buyer uses flexible contracts & $\begin{array}{l}\text { MIT Center for Transportation and } \\
\text { Logistics (2003), Stevenson, Spring (2007), } \\
\text { Tachizawa, Thomsen (2009), Pettit, Croxton, } \\
\text { Fiksel (2013), Tukamuhabwa et al. (2015), } \\
\text { Chowdhury, Quaddus (2016) }\end{array}$ & 3,5 \\
\hline 10 & $\begin{array}{l}\text { Buyer integrates various areas } \\
\text { within the firm }\end{array}$ & $\begin{array}{l}\text { Swafford, Ghosh, Murthy (2006), Tachizawa, } \\
\text { Thomsen (2009) }\end{array}$ & 6 \\
\hline 11 & $\begin{array}{l}\text { The costs of placing orders are } \\
\text { low }\end{array}$ & $\begin{array}{l}\text { Swafford, Ghosh, Murthy (2006), Tachizawa, } \\
\text { Thomsen (2009) }\end{array}$ & - \\
\hline 12 & $\begin{array}{l}\text { The time of placing orders } \\
\text { is short }\end{array}$ & $\begin{array}{l}\text { Swafford, Ghosh, Murthy (2006), Tachizawa, } \\
\text { Thomsen (2009) }\end{array}$ & - \\
\hline 13 & $\begin{array}{l}\text { Buyer involves suppliers in joint } \\
\text { product development activities }\end{array}$ & Tachizawa, Thomsen (2009) & $3,6,7$ \\
\hline 14 & $\begin{array}{l}\text { Buyer selects suppliers based } \\
\text { on their flexibility }\end{array}$ & $\begin{array}{l}\text { Tachizawa, Thomsen (2009), Gosling, } \\
\text { Purvis, Naim (2010), Zsidisin, Wagner (2010) }\end{array}$ & $\begin{array}{l}1,2,6,8 \\
7,8\end{array}$ \\
\hline 15 & $\begin{array}{l}\text { Buyer develops suppliers' } \\
\text { flexibility }\end{array}$ & $\begin{array}{l}\text { Gosling, Purvis, Naim (2010), Zsidisin, } \\
\text { Wagner (2010) }\end{array}$ & 3 \\
\hline
\end{tabular}

Source: own study.

Even if a business partner is flexible or the order has been efficiently switched to another supplier, the issue of rapid transportation remains uncertain. Therefore, the proposed approach highlights the role of a logistics service provider too (Table 8). Some authors indicate logistics (delivery) flexibility as one of the flexibility dimensions of the supply chain ${ }^{50}$. Other scientists underline that having flexible transportation is particularly important for SCRES ${ }^{51}$. Thus, the cooperation with the logistics company should be based on flexible possibilities.

The second key SCRES determinant is redundancy. It is usually related to multiple sourcing, back up suppliers ${ }^{52}$, safety stock and strategic inventory ${ }^{53}$. Flexibility and redundancy practices are often studied together ${ }^{54}$. Conducted research

50 L.K. Duclos, R.J. Vokurka, R.R. Lummus, A conceptual model...; I.N. Pujawan, Assessing supply chain flexibility...; A. Martínez Sánchez, M. Pérez Pérez, Supply chain flexibility and firm performance...; V. Kumar et al., Implementation and management framework for supply chain flexibility, "Journal of Enterprise Information Management" 2006, vol. 19, no. 3, pp. 303-319; K.A. Fantazy, V. Kumar, U. Kumar, An empirical study of the relationships among strategy, flexibility, and performance in the supply chain context, "Supply Chain Management: An International Journal” 2009, vol. 14, no. 3, pp. 177-188.

51 B.R. Tukamuhabwa et al., Supply chain resilience...; M. Kamalahmadi, M.M. Parast, A review of the literature...

52 M. Kamalahmadi, M.M. Parast, A review of the literature...

53 G.A. Zsidisin, S.M. Wagner, Do perceptions become reality?...; A. Ali, A. Mahfouz, A. Arisha, Analysing supply chain resilience...

54 B.R. Tukamuhabwa et al., Supply chain resilience...; M. Kamalahmadi, M.M. Parast, A review of the literature... 
demonstrates that there is no clear boundary between them. For example, Tachizawa and Thomsen, who highly contributed to assessing the flexibility in relationship with suppliers, presented more than twenty supply flexibility sources 55 . Among the mentioned variables, the authors also listed redundancy practices, i.e. inventory buffers or alternative suppliers. Similarly, the interviewed companies used the terms flexibility and redundancy practices interchangeably.

Table 8. Logistics flexibility - construct proposition

\begin{tabular}{|l|l|l|l|}
\hline No. & \multicolumn{1}{|c|}{ Item } & \multicolumn{1}{|c|}{ References } & \multicolumn{1}{|c|}{$\begin{array}{l}\text { Interview } \\
\text { no. }\end{array}$} \\
\hline 1 & $\begin{array}{l}\text { Buyer uses multiple } \\
\text { transportation modes }\end{array}$ & $\begin{array}{l}\text { Pujawan (2004), Tachizawa, Thomsen } \\
\text { (2009), Ishfaq (2012), Kamalahmadi, Parast } \\
\text { (2016), Zhao, Liu, Lopez (2017) }\end{array}$ & 1,3 \\
\hline 2. & $\begin{array}{l}\text { It is possible to choose a faster } \\
\text { mode of transportation in case } \\
\text { of emergency needs }\end{array}$ & Pujawan (2004) & 1,3 \\
\hline 3 & $\begin{array}{l}\text { It is possible to transport small } \\
\text { deliveries, with a volume } \\
\text { smaller than the load capacity } \\
\text { of the delivery vehicle/ } \\
\text { container }\end{array}$ & Pujawan (2004) & - \\
\hline 4 & $\begin{array}{l}\text { It is possible to mix different } \\
\text { products into a delivery load }\end{array}$ & Pujawan (2004) & - \\
\hline 5 & $\begin{array}{l}\text { Buyer collaborates with } \\
\text { logistics providers }\end{array}$ & Tachizawa, Thomsen 2009 & 1,3 \\
\hline
\end{tabular}

Source: own study.

For the purpose of this paper, it was decided to follow the well-known definition proposed by MIT Center for Transportation and Logistics ${ }^{56}$. Redundancy concerns maintaining capacity by keeping duplicated resources that are not utilized in a normal situation. In turn, during a crisis situation these are implemented to ensure the continuity of business processes. Hence, redundancy is considered to increase costs ${ }^{57}$. Following this understanding, the created construct consists of five items (Table 9).

55 E.M. Tachizawa, C.G. Thomsen, Assessing the effectiveness of supply flexibility sources: an empirical research, "International Journal of Production Research" 2009, vol. 47, no. 20, pp. 5791-5809.

56 MIT Center for Transportation and Logistics, Supply Chain Response to Terrorism..., pp. 31-32.

57 Y. Sheffi, J.B. Rice Jr., A supply chain view of the resilient enterprise, "MIT Sloan Management Review" 2005, vol. 47, no. 1, p. 41; M. Kamalahmadi, M.M. Parast, A review of the literature... 
Table 9. Redundancy in supplier-buyer cooperation - construct proposition

\begin{tabular}{|l|l|l|l|}
\hline No. & \multicolumn{1}{|c|}{ Item } & \multicolumn{1}{|c|}{ References } & $\begin{array}{c}\text { Interview } \\
\text { no. }\end{array}$ \\
\hline 1 & Buyers have backup suppliers & $\begin{array}{l}\text { Pagell et al. (2000), Yi, Ngai, Moon (2011), } \\
\text { Ivanov, Sokolov, Dolgui (2014), Hohenstein } \\
\text { et al. (2015), Chowdhury, Quaddus (2016), } \\
\text { Kamalahmadi, Parast (2016), Ali, Mahfouz, } \\
\text { Arisha (2017) }\end{array}$ & 2,3,8 \\
\hline 2 & $\begin{array}{l}\text { Buyers reserve slack capacity } \\
\text { with suppliers }\end{array}$ & $\begin{array}{l}\text { MIT Center for Transportation and Logistics } \\
\text { (2003), Park (2011), Chowdhury, Quaddus } \\
\text { (2016) }\end{array}$ & 3 \\
\hline 3 & $\begin{array}{l}\text { Buyers (or suppliers) keep } \\
\text { inventories }\end{array}$ & $\begin{array}{l}\text { MIT Center for Transportation and Logistics } \\
\text { (2003), Christopher, Peck (2004), Tachizawa, } \\
\text { Thomsen (2009), Zsidisin, Wagner (2010), } \\
\text { Tukamuhabwa et al. (2015), Ali, Mahfouz, } \\
\text { Arisha (2017) }\end{array}$ & $1,2,3,7$ \\
\hline 4 & $\begin{array}{l}\text { Buyers (or suppliers) keep } \\
\text { safety stocks }\end{array}$ & $\begin{array}{l}\text { Pagell et al. (2000), Sheffi, Rice (2005), Park } \\
\text { (2011), Ivanov, Sokolov, Dolgui (2014), } \\
\text { Chowdhury, Quaddus (2016), Ali, Mahfouz, } \\
\text { Arisha (2017), Datta (2017) }\end{array}$ & $2,3,8$ \\
\hline 5 & Buyers uses safety lead times & \begin{tabular}{l} 
Pagell et al. (2000) \\
\hline
\end{tabular} & $2,3,8$ \\
\hline
\end{tabular}

Source: own study.

The final, necessary aspect to use this framework concerns forming the research questions and the measurement scale. In order to ensure the questionnaire's simplicity and the its ease of completion for respondents, the same question for all constructs was applied: "Indicate to what extent you agree with the following statement?". In addition, following previous studies (Table 5), the use of five or six point Likert scale was proposed.

\section{Conclusions}

The conducted research enabled the construction of the first SCRES measurement framework presenting the perspectives of flexibility and redundancy in the area of relationships with suppliers. This approach can be used in future research to identify statistical dependencies between chosen issues and a resilient relationship with suppliers (Figure 7). For example, in the light of current global business trends, it would be interesting how such aspects as green product development, digitalization, triple bottom line risk management or circular economy practices influence supply chain resilience in terms of flexibility and redundancy in relationships with suppliers. It would also be worth understanding how the recognized resilient practices moderate supply chain performance (Figure 7). 


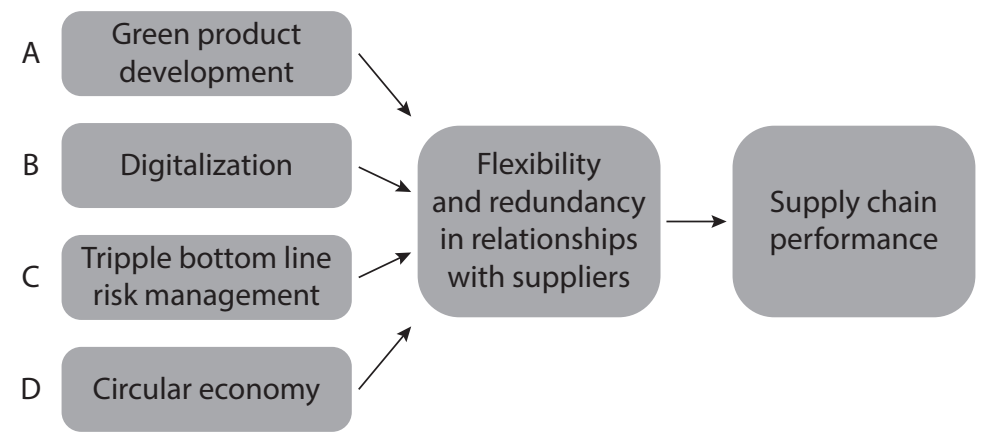

Figure 7. The examples of future research strings

Source: own study.

The paper has not only theoretical but also practical implications. All identified items can be a guide for managers on key determinants of building business resilience. All listed practices (Tables $6,7,8,9$ ) could also be recommended for relationships with other supply chain partners.

This work has its limitations. Primarily, it does not validate the presented measurement but only develops it. However, it can be assumed that the proposed framework is highly appropriate due to the fact that it is based not only on past SCRES studies, flexibility and redundancy constructs and items sofar confirmed but also the in-depth interviews IDIs, the results of which concur with the theory. Secondly, the literature review is based on just 39 papers. Nevertheless, methodical rigor and careful selection of SLR studies provided a wide input to the detailed measurement framework. Namely, the analyzed publications supported the identification of 33 measurable variables. In the future, it is worth supplementing the framework with other SCRES fundamental elements, which are: transparency and visibility, agility, collaboration and information sharing 58 .

\section{Acknowledgments}

This paper is an output of the science project "Flexibility in relationships with suppliers in terms of supplier-purchaser models of cooperation on product development in the B2B market", no. 2016/21/B/HS4/00665, financed by the National Science Centre (NCN) in Poland.

58 G. Wieteska, Design of resilient supply chains, "Economic and Social Development" 2018, pp. 571-578. 
References

Ali A., Mahfouz A., Arisha A., Analysing supply chain resilience: integrating the constructs in a concept mapping framework via a systematic literature review, "Supply Chain Management: An International Journal” 2017, vol. 22, no. 1, pp. 16-39.

Chang S.C., Yang C.L., Cheng H.C., Sheu C., Manufacturing flexibility and business strategy: an empirical study of small and medium sized firms, "International Journal of Production Economics" 2003, vol. 83, no. 1, pp. 13-26.

Chiang C.Y., Kocabasoglu-Hillmer C., Suresh N., An empirical investigation of the impact of strategic sourcing and flexibility on firm's supply chain agility, "International Journal of Operations \& Production Management” 2012, vol. 32, no. 1-2, pp. 49-78.

Chopra S., Sodhi M.S., Supply-chain breakdown, "MIT Sloan Management Review” 2004, vol. 46, no. 1, pp. 53-61.

Chowdhury M.M.H., Quaddus M., Supply chain readiness, response and recovery for resilience, "Supply Chain Management: An International Journal” 2016, vol. 21, no. 6, pp. 709-731.

Christopher M., Peck H., Building the resilient supply chain, "The International Journal of Logistics Management" 2004, vol. 15, no. 2, pp. 1-14.

Chu P.Y., Chang K.H., Huang H.F., How to increase supplier flexibility through social mechanisms and influence strategies?, "Journal of Business Industrial Marketing” 2012, vol. 27, no. 2, pp. $115-131$.

Datta P., Supply network resilience: a systematic literature review and future research, "The International Journal of Logistics Management” 2017, vol. 28, no. 4, pp. 1387-1424.

De Waart D., Getting Smart, "Supply Chain Management Review" 2006, vol. 10, no. 8, pp. 27-33.

Duclos L.K., Vokurka R.J., Lummus R.R., A conceptual model of supply chain flexibility, "Industrial Management Data Systems" 2003, vol. 103, no. 6, pp. 446-456.

Fantazy K.A., Kumar V., Kumar U., An empirical study of the relationships among strategy, flexibility, and performance in the supply chain context, "Supply Chain Management: An International Journal" 2009, vol. 14, no. 3, pp. 177-188.

Gosling J., Purvis L., Naim M.M., Supply chain flexibility as a determinant of supplier selection, "International Journal of Production Economics" 2010, vol. 128, no. 1, pp. 11-21.

Hohenstein N.O., Feisel E., Hartmann E., Giunipero L., Research on the phenomenon of supply chain resilience: a systematic review and paths for further investigation, "International Journal of Physical Distribution Logistics Management” 2015, vol. 45, no. 1/2, pp. 90-117.

Ishfaq R., Resilience through flexibility in transportation operations, "International Journal of Logistics Research and Applications" 2012, vol. 15, no. 4, pp. 215-229.

Ivanov D., Sokolov B., Dolgui A., The Ripple effect in supply chains: trade-off 'efficiency-flexibilityresilience' in disruption management, "International Journal of Production Research" 2014, vol. 52, no. 7, pp. 2154-2172.

Kamalahmadi M., Parast M.M., A review of the literature on the principles of enterprise and supply chain resilience: Major findings and directions for future research, "International Journal of Production Economics" 2016, vol. 171, pp. 116-133.

Karl A.A., Micheluzzi J., Leite L.R., Pereira C.R., Supply chain resilience and key performance indicators: a systematic literature review, "Production" 2018, vol. 28, pp. 1-16.

Kochan C.G., Nowicki D.R., Supply chain resilience: a systematic literature review and typological framework, "International Journal of Physical Distribution Logistics Management" 2018, vol. 48, no. 8, pp. 842-865.

Kumar V., Fantazy K.A., Kumar U., Boyle T.A., Implementation and management framework for supply chain flexibility, “Journal of Enterprise Information Management” 2006, vol. 19, no. 3, pp. 303-319. 
Lambert D.M., Cooper M.C., Issues in supply chain management, "Industrial Marketing Management" 2000, vol. 29, no. 1, pp. 65-83.

Lima F.R.P.D., Da Silva A.L., Godinho Filho M., Dias E.M., Systematic review: resilience enablers to combat counterfeit medicines, "Supply Chain Management: An International Journal" 2018, vol. 12, no. 3, pp. 117-135.

Martínez Sánchez A., Pérez Pérez M., Supply chain flexibility and firm performance: a conceptual model and empirical study in the automotive industry, "International Journal of Operations Production Management" 2005, vol. 25, no. 7, pp. 681-700.

Mentzer J.T., DeWitt W., Keebler J.S., Min S., Nix N.W., Smith C.D., Zacharia Z.G., Defining Supply Chain Management, "Journal of Business Logistics" 2001, vol. 22, no. 2, pp. 1-25.

MIT Center for Transportation and Logistics, Supply Chain Response to Terrorism: Creating Resilient and Secure Supply Chains, Interim Report of Progress and Learnings, August 8, 2003, http://webcache.googleusercontent.com/search?q=cache:zINMDk6KS3MJ:web.mit.edu/sc response/repository/SC_Resp_Report_Interim_Final_8803.pdf+\&cd=1\&hl=pl\&ct=clnk\&g l=pl\&client=firefox-b-d (accessed: 5.09.2020).

Norrman A., Jansson U., Ericsson's proactive supply chain risk management approach after a serious sub-supplier accident, "International Journal of Physical Distribution Logistics Management" 2004, vol. 34, no. 5, pp. 434-456.

Pagell M., Newman W.R., Hanna M.D., Krause D.R., Uncertainty, flexibility, and buffers: three case studies, "Production and Inventory Management Journal" 2000, vol. 41, no. 1, pp. 35-43.

Park K., Flexible and Redundant Supply Chain Practices to Build Strategic Supply Chain Resilience: Contingent and Resource-based Perspectives, PhD thesis, The University of Toledo, Toledo 2011.

Pereira C.R., Christopher M., Lago Da Silva A., Achieving supply chain resilience: the role of procurement, "Supply Chain Management: An International Journal" 2014, vol. 19, no. 5/6, pp. 626-642.

Pettit T.J., Croxton K.L., Fiksel J., Ensuring supply chain resilience: development and implementation of an assessment tool, "Journal of Business Logistics" 2013, vol. 34, no. 1, pp. 46-76.

Pujawan I.N., Assessing supply chain flexibility: a conceptual framework and case study, "International Journal of Integrated Supply Management" 2004, vol. 1, no. 1, pp. 79-97.

Ross D.F., Supply Chain Performance Measurement, APICS Profession Development, 2010, https:// pdf4pro.com/view/supply-chain-performance-measurement-apics-2401b4.html (accessed: 5.09.2020).

Sheffi Y., Rice Jr. J.B., A supply chain view of the resilient enterprise, "MIT Sloan Management Review" 2005, vol. 47, no. 1, pp. 40-48.

Shin N., Park S., Evidence-Based Resilience Management for Supply Chain Sustainability: An Interpretive Structural Modelling Approach, "Sustainability" 2019, vol. 11, no. 2, pp. 484-507.

Skipper J.B., Hanna J.B., Minimizing supply chain disruption risk through enhanced flexibility, “International Journal of Physical Distribution Logistics Management” 2009, vol. 39, no. 5, pp. 404-427.

Slack N., The flexibility of manufacturing systems, "International Journal of Operations Production Management" 2005, vol. 25, no. 12, pp. 1190-1200.

Stevenson M., Spring M., Supply chain flexibility: an inter-firm empirical study, "International Journal of Operations Production Management" 2009, vol. 29, no. 9, pp. 946-971.

Stone J., Rahimifard S., Resilience in agri-food supply chains: A critical analysis of the literature and synthesis of a novel framework, "Supply Chain Management: An International Journal" 2018, vol. 23, no. 3, pp. 207-238.

Supply Chain Council, Supply Chain Operations Reference Model, 2012, revision 11.0. 
Swafford P.M., Ghosh S., Murthy N., The antecedents of supply chain agility of a firm: scale development and model testing, "Journal of Operations Management" 2006, vol. 24, no. 2, pp. 170-188.

Tachizawa E.M., Thomsen C.G., Assessing the effectiveness of supply flexibility sources: an empirical research, "International Journal of Production Research" 2009, vol. 47, no. 20, pp. 5791-5809.

Tachizawa E.M., Thomsen C.G., Drivers and sources of supply flexibility: an exploratory study, "International Journal of Operations Production Management" 2007, vol. 27, no. 10, pp. 1115-1136.

Tranfield D., Denyer D., Smart P., Towards a methodology for developing evidence-informed management knowledge by means of systematic review, "British Journal of Management" 2003, vol. 14, no. 3, pp. 207-222.

Tukamuhabwa B.R., Stevenson M., Busby J., Zorzini M., Supply chain resilience: definition, review and theoretical foundations for further study, "International Journal of Production Research" 2015, vol. 53, no. 18, pp. 5592-5623.

Vickery S.N., Calantone R., Dröge C., Supply chain flexibility: an empirical study, “Journal of Supply Chain Management" 1999, vol. 35, no. 2, pp. 16-24.

Vokurka R.J., O'Leary-Kelly S.W., A review of empirical research on manufacturing flexibility, "Journal of Operations Management" 2000, vol. 18, no. 4, pp. 485-501.

Wieteska G., Design of resilient supply chains, "Economic and Social Development" 2018, pp. 571-578.

Yi C.Y., Ngai E.W.T., Moon K.L., Supply chain flexibility in an uncertain environment: exploratory findings from five case studies, "Supply Chain Management: An International Journal" 2011, vol. 16, no. 4, pp. 271-283.

Zhao G., Liu S., Lopez C., A literature review on risk sources and resilience factors in agri-food supply chains, [in:] L.M. Camarinha-Mathos, H. Afsarmanesh, R. Fornasiero (eds), Working Conference on Virtual Enterprises, Springer, Cham 2017, pp. 739-752.

Zsidisin G.A., Wagner S.M., Do perceptions become reality? The moderating role of supply chain resiliency on disruption occurrence, "Journal of Business Logistics” 2010, vol. 31, no. 2, pp. 1-20.

\section{Abstract}

The purpose of this paper is to present the proposal of a supply chain resilience (SCRES) measurement for the area of supplier relationship management. It is focused on two main SCRES elements, which are flexibility and redundancy. First, the article provides a multi-faceted analysis of publications that present systematic literature reviews on SCRES. Next, the results of several in-depth interviews on practices that increase resilience in relationships with suppliers are discussed. Finally, on the base of the conducted research, a measurement of flexibility and redundancy in relationships with suppliers is proposed. It covers four constructs which are: supplier flexibility, procurement flexibility, logistics flexibility and redundancy in supplier-buyer cooperation.

Keywords: SCRES, resilience, flexibility, redundancy, measurement, supplier 